\title{
EFEITO DO PTEROSTILBENO SOBRE A HOMEOSTASE REDOX PULMONAR PÓS-INFARTO DO MIOCÁRDIO EXPERIMENTAL
}

Silvio Tasca ${ }^{1}$, Vanessa Duarte Ortiz ${ }^{1}$, Denise Lacerda ${ }^{1}$, Adriane Belló-Klein ${ }^{1}$, Valquiria Bassani $^{2}$, Cristina Campos Carraro ${ }^{1}$, Alex Sander da Rosa Araújo ${ }^{1}$.

1-Laboratório de Fisiologia Cardiovascular, UFRGS, 2- Faculdade de Farmácia - UFRGS E-mail: stasca@hcpa.edu.br

Introdução: Após infarto agudo do miocárdio o tecido cardíaco sofre diversos danos, dentre eles a hipóxia, que ocasiona o aumento das espécies reativas de oxigênio, levando a um desequilíbrio redox no tecido cardíaco além de poder atingir outros tecidos periféricos como os pulmões. Assim, o uso de antioxidantes como o pterostilbeno poderia melhorar este quadro. Objetivo: Avaliar a ação do pterostilbeno na homeostasia redox em tecido pulmonar. Materiais e Métodos: Ratos Wistar machos (170g, n=6/grupo) foram divididos em três grupos: SHAM (controle), IAM (ratos infartados) e IAM+ptero (ratos infartados tratados com pterostilbeno). O IAM foi induzido através da técnica da ligadura da artéria coronária descendente anterior. O grupo controle foi submetido a todos os procedimentos cirúrgicos, com exceção da ligadura da artéria. Sete dias depois, iniciou-se o tratamento com pterostilbeno (100 mg/Kg por gavagem), durante 14 dias. Os ratos foram mortos por decapitação e os pulmões foram retirados para avaliação de dano oxidativo (TBARS) e de antioxidantes enzimáticos (atividades da superóxido dismutase e glutationa peroxidase) e não enzimáticos (Sulfidrilas). Resultados: observou-se uma redução significativa nos níveis de TBARS no grupo IAM+Ptero $(p<0,05)$, mas com relação aos resultados de sulfidrilas e glutationa peroxidase, não houve diferenças entre os grupos. No entanto a atividade da superóxido dismutase mostrou-se reduzida no grupo IAM e o tratamento com pterostilbeno foi capaz de aumentar significativamente a atividade desta enzima $(p<0,05)$. Conclusão: Nossos resultados preliminares sugerem que o infarto do miocárdio pode causar uma diminuição da proteção antioxidante nos pulmões. No entanto, o pterostilbeno parece proteger o tecido pulmonar contra o estresse oxidativo.

Comissão de ética no uso de animais da UFRGS: 35451

Apoio Financeiro: CAPES, CNPq 


\section{EFFECT OF PTEROSTILBENO ON PULMONARY REDOX HOMEOSTASE IN EXPERIMENTAL MYOCARDIAL INFARCTION}

Silvio Tasca ${ }^{1}$, Vanessa Duarte Ortiz ${ }^{1}$, Denise Lacerda ${ }^{1}$, Adriane Belló-Klein ${ }^{1}$, Valquiria Bassani $^{2}$, Cristina Campos Carraro ${ }^{1}$, Alex Sander da Rosa Araújo ${ }^{1}$.

1-Laboratório de Fisiologia Cardiovascular, UFRGS, 2- Faculdade de Farmácia - UFRGS E-mail: stasca@hcpa.edu.br

Introduction: After acute myocardial infarction (MI), cardiac tissue is severely damaged. Among these damages, it is highlighted tissue hypoxia, which causes a redox imbalance in the heart and in other peripheral tissues such as lungs. Thus, the use of antioxidants such as pterostilbeno could improve this scenario. Aim: This study aim was to evaluate the pterostilbeno effect in lung redox homeostasis. Materials and methods: Male Wistar rats (170g, $n=6$ / group) were allocated into three groups: SHAM (control), IAM (infarcted rats), IAM + ptero (infarcted rats treated with pterostilbene). MI was induced by anterior descending coronary artery ligation technique. Control group underwent all surgical procedures, with no artery ligation. Seven days later, treatment with pterostilbeno (100 $\mathrm{mg} / \mathrm{kg}$ per gavage) was started for 14 days. Rats were killed by decapitation and lungs were removed for evaluation of oxidative damage (TBARS) and enzymatic (superoxide dismutase and glutathione peroxidase activities) and non-enzymatic (Sulfhydriles) antioxidants. Results: There was a significant reduction in TBARS levels in the IAM + Ptero group ( $p$ <0.05). However no differences among the groups were found in sulfhydryl and glutathione peroxidase results. On the other hand, the activity of superoxide dismutase decreased in the IAM rats, and the treatment with pterostilbeno was able to significantly increase this enzyme activity $(p<0.05)$. Conclusion: Our preliminary results suggest that infarction may cause a decrease in antioxidant protection in the lungs. However, pterostilbeno seems to offer protection against oxidative stress in the lung tissue. 